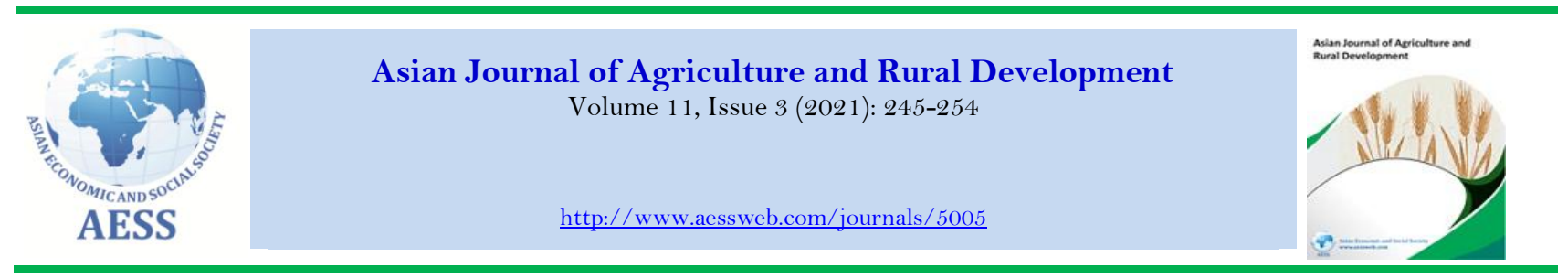

\title{
ORGANIC AGRICULTURE: FARMERS' PERCEPTION AND ADAPTATION IN NORTHERN THAILAND
}

Waripas Jiumpanyarach

\begin{tabular}{l}
\hline Article History \\
\hline Received: 9 June 2021 \\
Revised: 12 July 2021 \\
Accepted: 16 August 2021 \\
Published: 6 September 2021
\end{tabular}

\section{Keywords}

Attitudes

Perceived behavior

Costs of production

Conventional agriculture

Organic agriculture

Farmers' decision

Farm practices.
School of Agricultural Resources, Chulalongkorn University, Thailand.

\author{
$\triangle \underline{\text { waripas.j@,chula.ac.th }}$
}

\begin{abstract}
This study aimed to examine factors impacting on farmers' decision to convert from conventional to organic agriculture in Phayao and Nan Provinces, Thailand. The perceptions in conversion from conventional agriculture to organic agriculture toward the intention to change behavior, attitudes, and decision-making were analyzed. The data were collected by questionnaires administered to 124 farmers. The theory of planned behavior and the impacting factors of farm practices using logit model were used for analysis. The reasons for adopting organic agriculture were separated into three categories: (1) knowledge and understanding; farmers understood healthy farming but had little organic farm management information; (2) farm size impacts the costs of production; and (3) farm economics, including costs of delivery, storage, and markets, were a barrier to organic farming. These influenced attitudes, group norms, and perceived behavior. The study found that $50 \%$ of farmers using conventional practices were unwilling to change their practices, $16.1 \%$ had not decided, but $25.8 \%$ decided to change to organic practices. Organic agriculture in the study area increased to approximately $30.65 \%$. The study suggests that farmers' long-term benefits were implementation of agricultural policies supporting equipment, financial resources, knowledge, green technologies, training, and extension.
\end{abstract}

Contribution/Originality: This study contributes to the impact of factors on switching from conventional to organic farming in regard to socioeconomic and production procedures. This study used experimental choice and planned behavior models. The models tested various attributes of farmers' decisions.

DOI: $10.18488 /$ journal.ajard.2021.113.245.254

$\operatorname{ISSN}(\mathrm{P}):$ 2304-1455/ ISSN(E): 2224-4433

How to cite: Waripas Jiumpanyarach (2021). Organic Agriculture: Farmers' Perception and Adaptation in Northern Thailand. Asian Journal of Agriculture and Rural Development, 11(3), 245-254. 10.18488/journal.ajard.2021.113.245.254

(C) 2021 Asian Economic and Social Society. All rights reserved.

\section{INTRODUCTION}

Organic agriculture worldwide shows that consumers are turning to organic food and non-food as awareness increases of the health and environmentally friendly benefits. Over the last two decades, organic agriculture land has increased to approximately 72.3 million hectares (in 2019) globally, an increase of $1.6 \%$ from 2018. More than 5.9 million hectares, or $8 \%$, is organic agricultural land in Asia, which has the largest land, India, followed by China. The world's largest organic agricultural producer is China (51\% of global production). The largest market is the USA (Z44.7 billion euro , 42\%), followed by the European Union (41.4 billion euro, 39\%) and China (8.5 billion euro, $8 \%$ ). Tropical fruits from China were the biggest import in the European Union in 2019. There are 72 countries that have 
implemented organic regulation, including partial implementation, and drafting. Small-scale farmers in developing countries are focused on participatory guarantee systems (PGS). PGS is the best tool for small-scale farmers to access an affordable alternative to third-party certification. This will be an opportunity for them to access markets and increase the number of certified producers (Willer \& Lernoud, 2019).

Much research has focused on motivational factors relating to the adoption of organic agriculture. These factors, including socioeconomics characteristics, farm characteristics, attitudes, perception risks, sources of information, and national policies, influence farmers' decision making. National action plans, including market access, consumer demand, and organic standards, are applied to organic agricultural plans in developed countries such as in Europe, Japan, North America, and Oceania (Constance \& Choi, 2010; Janssen \& Hamm, 2014; Offermann, Nieberg, \& Zander, 2009; Vairo, Häring, Dabbert, \& Zanoli, 2009). In addition, farmers' lifestyle, health and environment aspects, moral, and social concerns are affected by farmers' attitudes (Best, 2010; Cranfield, Henson, \& Holliday, 2010; Koesling, Flaten, \& Lien, 2008). In contrast, developing countries are focused on farmers' financial resources, access to markets, domestic demand, government and private extension, and training facilities (Karki, Schleenbecker, \& Hamm, 2011; Schoonbeek et al., 2013; Thamaga-Chitja \& Hendriks, 2008). Economics aspects are the most important in adapting organic agriculture. PGS was initiated to help farmers in developing countries become certified at low cost (Buerkert \& Schlecht, 2017; Kirchner, 2015). The key factors influencing farmers' decisions are culture, farm characteristics, access to subsidies and member-associated groups, and health and environmental concerns (Shaban, 2015; Ullah et al., 2015). According to the agricultural system in current use, farmers' attitudes towards profit and production maximization have changed, and these are a major factor in the farm economy. The study of O'Riordan and Cobb (2001) investigated environmental economic and health benefits. The attitudes of organic farmers and consumers were studied: in particular, the factors influencing farmers to adopt organic farming, use of an ordered probit regression, and factors influencing attitudes toward organic farming - knowledge, experience, education, informational occupational effects, and individual aspects (Wheeler, 2008).

The Theory of Planned Behavior (TPB) explains a decision-maker's attitude towards performing behaviors. The attitudes are direct determinants of intention and behavior. The decision-maker's opinion is dependent upon judgment and behavior (Fishbein \& Ajzen, 1975). Subject norm controls the perceived behavior to perform (Ajzen, 1991). Perceived behavioral control convinced decision-makers able to perform the intended behavior and decisionmakers attribute this to several factors (Ajzen, 1991). Factors controlling farmers' behavior were attitudes, group norm, perceived behavior, risks of farming, and support by government policy (Yanakittkul \& Aungvaravong, 2020).

Organic farming is more beneficial than conventional agriculture in terms of a healthy environment, the economy, and the community. Thai farmers have opportunities due to good natural resources, but the infrastructure is limited. Since organic markets in Thailand, Asia, Europe, and the USA are expanding, the demand for safe foods has been rising. In converting to organic farming, a major challenge is the attitudes and behavior of individuals (Ajzen \& Fishbein, 2005). Most farmers in the study area decided to maintain conventional practices because of the appetite for, and aversion to agricultural risks (financial risks, production risks, quality and safety risks, and marketing risks). The trade-offs between the economic pressures of agricultural products and environmental objectives have been identified as reasons for changing farmers' practices. This research focused on smallholder farmers in Nan and Prayao Provinces focused small farming areas in Northern Thailand. Eighty percent of the population are farmers and have a low income level (Office of the National Economic and Social Development Board (NESDB), 2020). The geographic area is mountainous; the area has few water resources and a lack of water management. Compared to other regions (central, southern, and north-eastern), agricultural production in this region is the lowest. Additionally, the highest amounts of pesticides are consumed in this area because the area is mountainous and does not have access to water resources. Wild and non-wild lands are usually affected in the fire seasons due to the burning of crops after harvesting. Farmers in these regions prefer these practices because these are the cheapest and fastest way to clear the land for the next season. This is one of the air pollution problems in northern Thailand, having been recognized as a seasonal smog and haze crisis (Pardthaisong, Sin-ampol, Suwanprasit, \& Charoenpanyanet, 2018). This study aimed to analyze the factors that change processes in farm practices in Nan and Phayao Provinces in Thailand. The perceptions regarding switching from conventional to organic agriculture in the study areas were examined. Barriers related to attitudes, practices, and the economy were investigated. The research included a variety of viewpoints, job satisfaction values, and quality of life issues. The study predicted attitudes and other costs of production impacting farmers' adapting practices. Organic agriculture should be an option for farmers to raise their income, live in a good environment, and for their farming to become sustainable.

\section{DATA AND METHODOLOGY}

The methodology framework was divided into three steps: (1) selection of representative farm samples; (2) completion of questionnaires; and (3) analysis. The study population were farmers in Nan and Prayao Provinces; purposive sampling was used to select 124 farmers: 59 from Tumbon-Santa Aumpor-Narnoi, Nan Province, 23 from Tumbon-Banlao Aumpor-Mayjai, Phayao Province, 22 from Tumbon-Sritoi Aumpor-Mayjai, Phayao Province, and 20 from Tumbon-Parfak Aumpor-Mayjai, Phayao Province. Farms were selected considering four criteria: the farm system, farm size, farm location, and agreement to participate in the study. The data were collected from January to September 2019.

The questionnaires focused on:

1. Socioeconomic information: age, gender, education, farm owner, farm size, farm system, income, and household size. 
2. Farmer attitudes: individual aspects regarding organic agriculture and conventional agriculture included unique ideas, beliefs, competences, and identities.

3. Farm practices: organic farming practices, conventional farming practices, production processes, costs of conventional production, costs of organic production, logistic, and markets.

4. Suggestion: market, knowledge, information, and logistic.

Other secondary information was retrieved from the Department of Internal Trade, Ministry of Commerce, Customs Department, Ministry of Finance, Office of Agricultural Economics, and Ministry of Agriculture and Cooperatives in Thailand. This study was completed based on field research and documentary research.

The questions were indicators for development in farming practices and market strategies. The first indicator concerned organic farming attitudes, which included the production process using satisfaction levels (low, moderate, high, highest). The second indicator was farmers' income levels, which impact farmers' behavior. This research examined the attitudes and perceptions of the benefits of health and decreasing chemical contamination from organic farming. The TPB was used to explain farmers' intentions towards organic farming. Attitudes toward organic farming behavior, subject norm influences on organic farming behavior, and perceived behavior control towards organic farming behavior were the three key factors regarding intention to adopt organic farming (Table 1).

Table-1. Attribute questions for farmers' switching decision.

\begin{tabular}{|c|c|c|}
\hline Attribute & Questions & Attribute category \\
\hline \multirow[t]{4}{*}{ Attitudes: products } & \multirow{4}{*}{$\begin{array}{l}\text { What is the level of your satisfaction } \\
\text { with products? }\end{array}$} & Satisfied with conventional products \\
\hline & & Satisfied with organic products \\
\hline & & $\begin{array}{l}\text { Satisfied with organic more than conventional } \\
\text { products }\end{array}$ \\
\hline & & Satisfied with conventional practices \\
\hline $\begin{array}{l}\text { Attitudes: } \\
\text { farm practices }\end{array}$ & $\begin{array}{l}\text { What is the level of your satisfaction } \\
\text { with farm practices? }\end{array}$ & Satisfied with organic practices \\
\hline \multirow{5}{*}{$\begin{array}{l}\text { Subject norm: } \\
\text { product markets }\end{array}$} & \multirow{3}{*}{$\begin{array}{l}\text { What is the level of your satisfaction } \\
\text { with delivery to markets? }\end{array}$} & Fresh market \\
\hline & & Modern trade/supermarket \\
\hline & & Organic/green market \\
\hline & \multirow{2}{*}{$\begin{array}{l}\text { What is the level of your satisfaction } \\
\text { with marketing? }\end{array}$} & Conventional product marketing \\
\hline & & Organic product marketing \\
\hline $\begin{array}{l}\text { Subject norm: } \\
\text { product standards }\end{array}$ & $\begin{array}{l}\text { What is the level of your satisfaction } \\
\text { with product standards? }\end{array}$ & Satisfied with organic standards \\
\hline \multirow{4}{*}{$\begin{array}{l}\text { Attitudes: } \\
\text { product delivery }\end{array}$} & \multirow{4}{*}{$\begin{array}{l}\text { What is the level of your satisfaction } \\
\text { with costs of delivery? }\end{array}$} & Costs of organic product storage \\
\hline & & Additional delivery costs of organic products \\
\hline & & Conventional products \\
\hline & & Organic products \\
\hline \multirow{2}{*}{$\begin{array}{l}\text { Perceived behavior: } \\
\text { organic farming } \\
\text { knowledge and information }\end{array}$} & \multirow{2}{*}{$\begin{array}{l}\text { What is the level of your knowledge of } \\
\text { organic farming? }\end{array}$} & Understanding \\
\hline & & Knowledge \\
\hline \multirow{5}{*}{$\begin{array}{l}\text { Perceived behavior: access } \\
\text { to knowledge and } \\
\text { information }\end{array}$} & \multirow{5}{*}{$\begin{array}{l}\text { How do you access information and } \\
\text { knowledge? }\end{array}$} & Extension from the government/academic \\
\hline & & Extension from the private sector \\
\hline & & Convenient \\
\hline & & Fast \\
\hline & & Satisfied \\
\hline
\end{tabular}

\subsection{Econometric Method}

In the choice experiment, the respondents chose different attributes for organic practices. Their opinions and attitudes regarding farm practices reflect the farm economy. The model tested different attributes of farmers' decisions. Regarding farmers' choices, bias was a concern due to the decision situation (Greene, 2003; Lusk \& Schroeder, 2004). The estimation determined the impacts of factors (education, family members, number of conventional farms, number of organic farms, and costs of production) on the farm economy. This analysis uses descriptive statistics and a regression model run by the SAS 8.0 program. The results explain farmers' decision toward farm practice, providing important information related to future organic practices and promoting organic practices and organic markets in the future.

The model analyzed variables that influence the farm economy. The equation is follows:

where

$$
Y=\beta_{0}+\beta_{1} X_{1}+\beta_{2} X_{2}+\cdots+\beta_{n} X_{n}
$$

$$
\begin{gathered}
Y=\text { Farm decision } \\
\beta_{0}=\text { Constant } \\
\beta_{i, \ldots, n}=\text { Coefficient of variables, } \mathrm{i}=1, \ldots, \mathrm{n} \\
X_{i, \ldots, n}=\text { Dependent variables, } \mathrm{i}=1, \ldots, \mathrm{n}
\end{gathered}
$$


The empirical specification is as follows:

Model 1:

Farm decision $=\beta_{0}+\beta_{1} G E N+\beta_{2} A G E+\beta_{3} M E M+\beta_{4} E D U+\beta_{5} C O N V+\beta_{6} O R G+\beta_{7} \operatorname{COST}+\beta_{8} I N C O M E I L$ where

$$
\beta_{i, \ldots, n}=\text { Coefficient of variables, } \mathrm{i}=1, \ldots, \mathrm{n}
$$

Model 1:

$i=G E N, A G E, M E M, E D U, C O N V, O R G, C O S T, I N C O M E I L$

Model 2:

$i=G E N, A G E, M E M, E D U, O R G, C O S T, I N C O M E I L$

Model 3:

$i=G E N, A G E, M E M, E D U, C O N V, O R G, C O S T, I N C O M E I L, S A T C O N P D, S A T C O N P T, S T D$

Model 4:

$i$

$=G E N, A G E, M E M, E D U, C O N V$, ORG, COST, INCOMEIL,UNDORG FMKT MMKT OMKT ORGSTORAGE, SATDELIVERY

Model 5:

$i$

$=G E N, A G E, M E M, E D U, C O N V, O R G, C O S T, I N C O M E I L, E X T G O V, E X T P R I, A C C C O N, A C C F A S T, A C C S A T, K N O O R G$

Model 6

$i=G E N, A G E, M E M, E D U, C O N V, O R G, C O S T, I N C O M E I L, S A T O R G P D, S A T O R G P T$

Model 7

$i=G E N, A G E, M E M, E D U, C O N V, O R G, C O S T, I N C O M E I L, U N D O R G, F M K T, M M K T, O M K T$

These variables are GEN = gender, $\mathrm{AGE}=$ age $\mathrm{MEM}=$ family member, $\mathrm{EDU}=$ education level, $\mathrm{CONV}=$ number of conventional farms, $\mathrm{ORG}=$ number of organic farms, COST $=$ cost of organic production, INCOMEIL $=$ income levels, SATCONPD = satisfied with conventional products, SATCONPT = satisfied with conventional practices, SATORGPD = satisfied with organic products, SATORGPT $=$ satisfied with organic practices, $\mathrm{STD}=$ organic standard, UNDORG = understand organic agriculture, FMKT $=$ satisfied with farmer markets, MMKT $=$ satisfied with modern markets, OMKT = satisfied with organic markets, ORGSTORAGE = satisfied with organic storage, SATDELIVERY = satisfied with product delivery, EXTGOV = satisfied with extension from government, EXTPRI = satisfied with extension from private sector, ACCCONV = convenient access information, ACCFAST $=$ fast access information, ACCSAT $=$ satisfied with access information, KNOORG = knowledge of organic agriculture.

Table-2. Descriptive statistics of the explanatory variables: age, family members, educational level, agricultural areas, income levels, and costs of production

\begin{tabular}{|c|c|c|c|c|c|}
\hline Variable & & $\%$ & Variable & & $\%$ \\
\hline \multirow[t]{2}{*}{ Gender } & Male & 69 & Educational level & Below kindergarten & 6.45 \\
\hline & Female & 31 & & Kindergarten & 32.3 \\
\hline \multirow[t]{7}{*}{ Age, years } & $<15$ & 3.23 & & Junior high school & 33.1 \\
\hline & $16-25$ & 6.45 & & High school & 16.9 \\
\hline & $26-35$ & 17.7 & & Vocational school & 4.03 \\
\hline & $36-45$ & 21.8 & & Graduated & 2.42 \\
\hline & $46-55$ & 31.5 & $\begin{array}{l}\text { Conventional agriculture } \\
\text { area, rai }\end{array}$ & $\leq 5$ & 36.13 \\
\hline & $56-65$ & 11.3 & & $6-10$ & 22.69 \\
\hline & $>65$ & 3.23 & & $11-15$ & 10.08 \\
\hline \multirow{7}{*}{$\begin{array}{l}\text { Income, } \\
\text { (annual, baht) }\end{array}$} & $180,000-300,000$ & 37.1 & & $16-20$ & 17.68 \\
\hline & $300,000-540,000$ & 46.8 & & $>20$ & 13.45 \\
\hline & $540,000-660,000$ & 1.61 & Organic agriculture area, rai & $\leq 5$ & 18.49 \\
\hline & $600,000-780,000$ & 0.81 & & $6-10$ & 10.92 \\
\hline & $780,000-900,000$ & 1.61 & & $11-15$ & 4.20 \\
\hline & $900,000-1,000,000$ & $\mathrm{O}$ & & $16-20$ & 4.20 \\
\hline & $>1,000,000$ & 3.83 & & $>20$ & 1.68 \\
\hline \multirow{3}{*}{$\begin{array}{l}\text { Costs of } \\
\text { production, } \\
\text { (annual, baht) }\end{array}$} & $\leq 50,000$ & 46.22 & Farm practices & $\begin{array}{l}\text { Conventional } \\
\text { agriculture }\end{array}$ & 64.49 \\
\hline & $50,000-100,000$ & 52.94 & & Organic agriculture & 18.12 \\
\hline & $>100,000$ & 5.88 & & $\begin{array}{l}\text { Conventional and } \\
\text { organic agriculture }\end{array}$ & 17.39 \\
\hline
\end{tabular}

Note: Baht: Thai currency exchange in US $\$$ is based on the exchange rates from Siam Commercial Bank June $1,2019(1$ US dollar $=31.47$ baht) 


\section{RESULTS}

\subsection{Description of Statistics}

The characteristics of representative farmers in Payao and Nan Provinces are based on surveys of 124 farmers. Farmers' attributes are presented in Table 3.

The study found that the majority of farmers in the area, $46.8 \%$, have an income that ranges from 300,000 to 540,000 baht and $37.1 \%$ have an income that ranges from 180,000 to 300,000 baht (Table 2). According to the Office of the National Economic and Social Development Board (NESDB), the annual income per capita in 2019 was 240,568.7 baht, which the majority of farmers have. This showed the farmers have an income that is either at or below the average national income per capita in Thailand (NESDB, 2020). There is a small variation in farmers' income: $36.13 \%$ of farmers ran small-scale conventional farms $(\leq 5$ rai) and $18.49 \%$ ran small-scale organic farms $(\leq 5$ rai).

Table-3. Levels of farm practice satisfaction.

\begin{tabular}{|c|c|c|c|c|c|}
\hline \multirow[b]{2}{*}{ Attribute } & \multirow[b]{2}{*}{ Attribute category } & \multicolumn{4}{|c|}{ Percentage (\%) } \\
\hline & & $\begin{array}{c}\text { Low } \\
(1)\end{array}$ & $\begin{array}{l}\text { Moderate } \\
(2)\end{array}$ & $\begin{array}{c}\text { High } \\
(3)\end{array}$ & $\begin{array}{c}\text { Highest } \\
(4)\end{array}$ \\
\hline \multirow[t]{2}{*}{ Products } & $\begin{array}{lll}\begin{array}{l}\text { Satisfied with conventional } \\
\text { products }\end{array} & \\
\end{array}$ & $\overline{0}$ & 14.5 & 21 & 40.3 \\
\hline & Satisfied with organic products & 5.65 & 25 & 41.1 & 17.7 \\
\hline \multirow[t]{2}{*}{ Farm practices } & $\begin{array}{l}\text { Satisfied with conventional } \\
\text { practices }\end{array}$ & 8.87 & 21 & 51.6 & 10.5 \\
\hline & Satisfied with organic practices & 17.7 & 27.4 & 39.5 & 6.45 \\
\hline \multirow[t]{3}{*}{ Product markets } & Fresh market & 12.1 & 18.5 & 35.5 & 25 \\
\hline & Modern trade/supermarket & 53.2 & 16.1 & 18.5 & 2.42 \\
\hline & Organic/green market & 42.7 & 21 & 23.4 & 4.03 \\
\hline Product standards & Satisfied with organic standards & 17.7 & 27.4 & 39.5 & 6.45 \\
\hline \multirow[t]{4}{*}{ Product delivery } & Costs of organic product storage & 6.45 & 27.4 & 43.5 & 12.9 \\
\hline & $\begin{array}{l}\begin{array}{l}\text { Additional delivery costs of } \\
\text { organic products }\end{array} \\
\end{array}$ & 16.9 & 23.4 & 45.2 & 5.65 \\
\hline & Conventional products & 6.45 & 28.2 & 46 & 7.26 \\
\hline & Organic products & 9.68 & 28.2 & 49.2 & 4.03 \\
\hline \multirow[t]{2}{*}{$\begin{array}{lr}\text { Organic } & \text { Farming } \\
\text { Knowledge } & \text { and } \\
\text { Information } & \\
\end{array}$} & Understanding & 5.65 & 12.1 & 27.4 & 39.5 \\
\hline & Knowledge & 6.45 & 16.1 & 50.8 & 17.7 \\
\hline \multirow[t]{2}{*}{ Extension } & $\begin{array}{l}\text { Extension from } \\
\text { government/academia }\end{array}$ & 16.9 & 38.7 & 32.3 & 4.84 \\
\hline & Extension from the private sector & 37.1 & 19.4 & 29.8 & 4.84 \\
\hline \multirow[t]{3}{*}{$\begin{array}{l}\text { Access Knowledge and } \\
\text { Information }\end{array}$} & Convenient & 49.2 & 24.2 & 16.1 & 2.42 \\
\hline & Fast & 53.2 & 18.5 & 16.9 & 3.23 \\
\hline & Satisfied & 55.6 & 18.5 & 14.5 & 3.23 \\
\hline
\end{tabular}

Table 3 shows the satisfaction levels of farmers in different categories. Major farmers had positive attitudes toward organic farming, measured on five-point Likert scale from $1=$ strong disagree to $4=$ strongly agree. Farmers rated many statements positively regarding knowledge, understanding, farm practices, production, and farm economy. Farmers' decision making toward organic agriculture adaption were focused on: (1) attitudes toward organic farming behavior refer to positive attitudes towards organic agriculture behavior and intend to perform organic agriculture showed that the attitudes of farmers had a mean score of 2.2864 for conventional products, 2.1337 for satisfaction with organic standards, 2.421 for cost of organic storage, 2.1863 for additional costs of delivery of organic and conventional products, and 2.2793 for organic products. The products related to number of farming areas, which implied farmers' positive attitude on both types of product. (2) Subject norm influences on organic agriculture referring to influencing farmers behavior toward organic farming decision showed a mean score of 1.4028 for farmers satisfied with modern trade/supermarket, 1.4028 for organic/green markets, and 2.5326 on fresh markets. (3) Perceived behavior controlled the intention to switch to organic farming showed a mean score of 2.6896 for understanding, 2.606 for knowledge, 1.7748 for private sector extension, 1.4606 for access to information and knowledge, and 2.0729 for extension from government and academia. Convenient, fast, and satisfaction on access knowledge and information scored 1.4606, 1.4352, and 1.3826, respectively. 


\subsection{Factors Impacting on Farmers' Decision}

Regarding the logit model, seven different models were comparing among different impacting factors in each models regarding farmers' decision to switch to organic agriculture. The study found that all seven models had negatively impacted the size of the conventional farm and costs of production. In contrast, the results showed a positive impact on the size of organic farm. The results showed that farmers' decision making to switch to organic agriculture depended upon costs of production and farm size. Farmers considering a switch to organic agriculture had to spend more money on preparing infrastructure and did not expect to receive a high return on organic products. Farmers who possessed more conventional farmland would not switch to organic farming. The factors impacting on farmers' decision are presented in Table 4

With respect to costs of production and area of conventional agriculture land, these had a negative impact on farmers' decisions. Farmers who had high production costs were not willing to change to organic agriculture. The results showed that the more conventional the agricultural land, the less likely a changed to organic agriculture. Changing to organic agriculture had many concern or farmers, including costs of production, labour, productivity, market, and quality standards (Cristache, Vuță, Marin, Cioacă, \& Vuţă, 2018; Darnhofer, Lindenthal, BartelKratochvil, \& Zollitsch, 2010). Furthermore, the majority of farmers were satisfied with the logistics information relating to modern trade, supermarkets, and conventional markets. Product standards were limited in accessing modern trade. Fresh markets or farmer markets were available for small-scale farmers in rural areas. Small-scale farmers, especially organic farmers, had few connections to modern trade, supermarkets, or organic markets.

Table-4. Estimated factors impacting farmers' decision toward organic farming using seven choice experiment logit models.

\begin{tabular}{|c|c|c|c|c|c|c|c|}
\hline & Model 1 & Model 2 & Model 3 & Model 4 & Model 5 & Model 6 & Model 7 \\
\hline \multirow[t]{2}{*}{ Intercept } & 1.1259 & 1.0716 & -3.8385 & -1.3489 & -1.4735 & -3.3921 & -2.5368 \\
\hline & $(1.3313)$ & $(1.3248)$ & $(3.3941)$ & $(3.9182)$ & $(5.7313)$ & $(3.2935)$ & $(3.9059)$ \\
\hline \multirow[t]{2}{*}{ Age } & -0.1145 & -0.1028 & 0.1879 & 0.2032 & -0.3810 & 0.0917 & 0.1776 \\
\hline & $(0.1642)$ & $(0.1613)$ & $(0.4928)$ & $(0.5248)$ & (0.8920) & $(0.4686)$ & $(0.5072)$ \\
\hline \multirow[t]{2}{*}{ Gender } & 0.3057 & 0.3077 & 0.6109 & -0.1002 & 0.6340 & 0.8174 & 0.0816 \\
\hline & $(0.4038)$ & $(0.4035)$ & $(0.8161)$ & $(0.8941)$ & $(1.1313)$ & $(0.7776)$ & $(0.7967)$ \\
\hline \multirow[t]{2}{*}{ Education } & -0.0634 & -0.0534 & -0.2618 & -0.1672 & -0.2899 & -0.2981 & -0.3029 \\
\hline & $(0.1887)$ & $(0.1873)$ & (0.3913) & (0.4369) & $(0.6045)$ & $(0.3771)$ & $(0.4206)$ \\
\hline \multirow[t]{2}{*}{ Income level } & 0.3503 & 0.3447 & 0.1008 & 0.1618 & -0.00919 & 0.1483 & 0.1230 \\
\hline & $(0.2687)$ & $(0.2674)$ & (0.2089) & $(0.2678)$ & $(0.5164)$ & $(0.2038)$ & $(0.2639)$ \\
\hline \multirow[t]{2}{*}{ Family member } & -0.1555 & -0.1602 & & & & & \\
\hline & $(0.1205)$ & $(0.1197)$ & & & & & \\
\hline \multirow{2}{*}{$\begin{array}{l}\text { Conventional } \\
\text { area }\end{array}$} & $-0.0107^{*}$ & $-0.00789^{*}$ & $-0.0987^{* *}$ & $-0.1319^{* *}$ & -0.1597 & $-0.0647^{* *}$ & $-0.0691^{* *}$ \\
\hline & $(0.0276)$ & $(0.0266)$ & $(0.0871)$ & $(0.1013)$ & $(0.1425)$ & $(0.0807)$ & $(0.0707)$ \\
\hline \multirow[t]{2}{*}{ Organic area } & $0.0160^{*}$ & & $0.0606^{* *}$ & $0.1082^{* *}$ & $0.1101^{* * *}$ & $0.0423^{* *}$ & $0.0424^{* *}$ \\
\hline & $(0.0377)$ & & (0.0927) & $(0.1062)$ & $(0.0925)$ & $(0.0866)$ & (0.0834) \\
\hline \multirow{2}{*}{$\begin{array}{ll}\text { Costs } & \text { of } \\
\text { production }\end{array}$} & $-0.00002^{*}$ & $-0.00002^{*}$ & $-1.69 \mathrm{E}-6^{*}$ & $-0.00002^{*}$ & $0.000016^{*}$ & $-7.7 \mathrm{E}-6^{*}$ & $-0.00001^{*}$ \\
\hline & $(9.324 \mathrm{E}-6)$ & $(9.262 \mathrm{E}-6)$ & $(0.000015)$ & $(0.000019)$ & $(0.000026)$ & $(0.000013)$ & $(0.000016)$ \\
\hline \multirow[t]{2}{*}{$\begin{array}{l}\text { Satisfied with } \\
\text { organic products }\end{array}$} & & & 0.4325 & & & 0.0948 & \\
\hline & & & $(0.7517)$ & & & $(0.4600)$ & \\
\hline \multirow[t]{2}{*}{$\begin{array}{l}\text { Satisfied with } \\
\text { conventional } \\
\text { products }\end{array}$} & & & -0.3275 & & & & \\
\hline & & & $(0.6266)$ & & & & \\
\hline \multirow[t]{2}{*}{$\begin{array}{l}\text { Satisfied with } \\
\text { organic practices }\end{array}$} & & & -0.2688 & & & 0.7323 & \\
\hline & & & (0.9268) & & & (0.5494) & \\
\hline \multirow[t]{2}{*}{$\begin{array}{l}\text { Satisfied with } \\
\text { conventional } \\
\text { practices }\end{array}$} & & & 1.1468 & & & & \\
\hline & & & $(0.8925)$ & & & & \\
\hline \multirow[t]{2}{*}{$\begin{array}{l}\text { Understand } \\
\text { organic } \\
\text { agriculture }\end{array}$} & & & & 1.3223 & & & 1.0815 \\
\hline & & & & $(0.6111)$ & & & $(0.4835)$ \\
\hline \multirow[t]{2}{*}{$\begin{array}{l}\text { Satisfied with } \\
\text { farmers' markets }\end{array}$} & & & & $0.9146^{* * * * *}$ & & & 0.3981 \\
\hline & & & & $(0.6421)$ & & & (0.4322) \\
\hline
\end{tabular}




\begin{tabular}{|c|c|c|c|c|c|c|c|}
\hline & Model 1 & Model 2 & Model 3 & Model 4 & Model 5 & Model 6 & Model 7 \\
\hline \multirow[t]{2}{*}{$\begin{array}{l}\text { Satisfied with } \\
\text { modern markets }\end{array}$} & & & & 0.4290 & & & 0.1722 \\
\hline & & & & $(0.7058)$ & & & $(0.6746)$ \\
\hline \multirow[t]{2}{*}{$\begin{array}{l}\text { Satisfied with } \\
\text { organic markets }\end{array}$} & & & & -1.2221 & & & -0.8464 \\
\hline & & & & $(0.8110)$ & & & $(0.7221)$ \\
\hline \multirow[t]{2}{*}{$\begin{array}{l}\text { Satisfied with } \\
\text { organic storage }\end{array}$} & & & & -1.0465 & & & \\
\hline & & & & $(0.7825)$ & & & \\
\hline \multirow[t]{2}{*}{$\begin{array}{l}\text { Satisfied with } \\
\text { product delivery }\end{array}$} & & & & -0.0766 & & & \\
\hline & & & & $(0.9781)$ & & & \\
\hline \multirow[t]{2}{*}{$\begin{array}{lr}\text { Satisfied } & \text { with } \\
\text { extension } & \text { from } \\
\text { government } & \\
\end{array}$} & & & & & 0.3894 & & \\
\hline & & & & & (0.8209) & & \\
\hline \multirow[t]{2}{*}{$\begin{array}{ll}\text { Satisfied } & \text { with } \\
\text { extention } & \text { from } \\
\text { private sector }\end{array}$} & & & & & 1.6902 & & \\
\hline & & & & & $(1.3419)$ & & \\
\hline \multirow[t]{2}{*}{$\begin{array}{l}\text { Convenient } \\
\text { access } \\
\text { information }\end{array}$} & & & & & 0.00279 & & \\
\hline & & & & & 3.0030 & & \\
\hline \multirow[t]{2}{*}{$\begin{array}{ll}\text { Fast access } & \text { to } \\
\text { information } & \\
\end{array}$} & & & & & 0.2060 & & \\
\hline & & & & & 2.3395 & & \\
\hline \multirow[t]{2}{*}{$\begin{array}{ll}\text { Satisfied with } & \\
\text { access } & \text { to } \\
\text { information } & \\
\end{array}$} & & & & & -3.6452 & & \\
\hline & & & & & 2.8871 & & \\
\hline \multirow[t]{2}{*}{$\begin{array}{l}\text { Knowledge of } \\
\text { organic } \\
\text { agriculture }\end{array}$} & & & & & 1.6086 & & \\
\hline & & & & & 1.1172 & & \\
\hline
\end{tabular}

\subsection{Description of Decision Criteria}

Farmers' decisions must be considered in regard to costs of production, size of conventional farm, and size of organic farm before they consider other factors. Farmers' attitudes, including satisfaction with products, logistics, markets, knowledge, and agricultural information, were of secondary impact on farmers' decision on which agricultural practice to adopt in these models. The structure of farmers' decisions showed that they considered the costs of production, which are related to number of farms owned. The study separated switching decisions into three criteria, as follows.

Criterion I focused on knowledge and understanding. The questions assessed the levels of organic farming knowledge and information from government, academia, and the private sector. Extension provided health and environmental friendly information of farm practices. The questions asked to farmers considered whether they would understand and had knowledge. Farmers did not answer positively and did not perceive their farming to be safe due to their access to information, which was very poor. The results showed the difference in attitudes between conventional and organic farming. Farmers considered that organic farming was more environmentally friendly and healthy than conventional farming.

Criterion II addressed farm size, i.e. farmers who were not willing to risk the foregoing. Farmers' decisions must be consider conventional and organic farm size before they consider other factors. The adapting decision depended upon farm area owned. The decision model showed that the area of organic farmland had a positive impact; in contrast, regarding the costs of products for conventional farmlands, this had a negative impact on farmers' decision to adopt organic practices.

Criterion III focused on farm economics. Conventional and organic products had a high level of individual farmers' norm. These reflected the costs of delivery and fresh markets. Costs of products, including storage, delivery, and organic products, impacted on farmers' decisions. By contrast, the results of modern trade and organic markets showed a low level of satisfaction. Regarding satisfaction with markets and standards of products, farmers' intention 
to improve organic practices focused on (1) costs of delivery, storage, and products and (2) markets. Market availability for organic products was an essential factor that motivates farmers to switch to organic agriculture.

As expected, farmers who agreed that conventional agriculture is more profitable than organic agriculture were more likely to be satisfied with conventional markets (modern trade) and supportive of the private sector, while others were of the opinion that organic farming had more environmentally friendly standards, fresh markets, and government and academia support than conventional agriculture. However, many farmers think organic market is a niche and that supply could rise faster than demand, leading to reduced prices.

\subsection{Farmers' Decision to Switch to Organic Agriculture}

Approximately $17.39 \%$ of farmers practised both conventional and organic agriculture, $64.49 \%$ conventional agriculture only, and $18.12 \%$ organic agriculture only. Regarding farmers' decision to convert from conventional to organic agriculture, results varied: $25.8 \%$ of farmers in conventional agriculture decided to change to organic agriculture, $50 \%$ of farmers in conventional agriculture were not willing to change their practices, and $8.1 \%$ used both conventional and organic agriculture. A total of $16.1 \%$ of farmers had decided not to become organic farmers.

The decisions whether to switch to organic agriculture are presented in Figure 1.

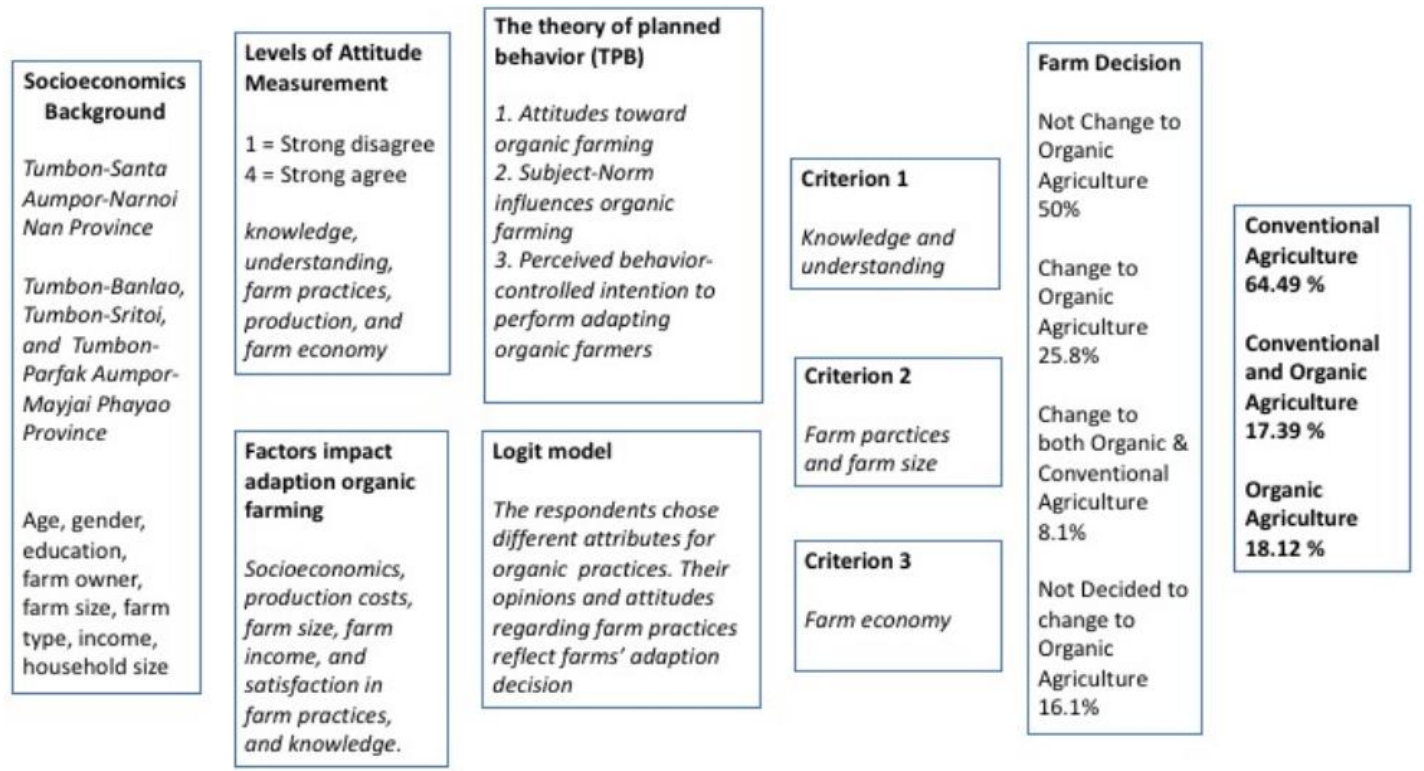

Figure-1. Farmers' decisions regarding switching to organic agriculture.

\section{DISCUSSION AND CONCLUSIONS}

The theoretical and methodological approach of the study implemented TPB and decision-making factors as a framework. The decision-maker's intention performs a behavior according to their attitudes towards their behaviors, and their perceived opinions are applied to perceived behavior (Fishbein \& Ajzen, 1975). The approaches were analyzed and examined throughout the theoretical model. Subject norms played a major role in forming behavior intention and understanding the decision making of northern Thai farmers regarding switching to organic agriculture. The model included attitudes, perceptions, subject norms, and beliefs about different aspects of organic agriculture (economic, environmental, and health) regarding the decision to switch to organic farming. The level of farmers' knowledge and awareness had direct effects on behavioral intention (Terano, Mohamed, Shamsudin, \& Latif, 2015). The influence of perceived social pressure and perceived behaviural control were found to be influential on farmers' behavioural intention (Asadollahpour, Najafabadi, \& Hosseini, 2016). Farmers had strongly intentions to convert to organic agriculture using low chemical inputs and following organic practices. The results showed that approximately two-thirds of farmers in the study area had views on organic farming and were willing to switch. Those attitudes (knowledge and understanding) had indirect effects on behavioral intention. The positive aspect of organic practices was the low costs of land preparation. Furthermore, the adaption decision was different for farmers with a high level of education while age and experience played only a small role in intention. Farm size showed a direct influence on farmers' intention to convert to organic farming.

There was strong evidence that farmers were more likely to feel positively towards organic agriculture, which was the most consistent predictor of farmers' intention toward organic agriculture (attitudes toward organic farming, norm of organic farming, and perceived behavior organic farming). Most elderly farmers, who believe that conventional agriculture is currently unsustainable, were more likely to be looking for alternative farming practices. Organic farming had a positive role inn organic farming by producing net benefits, and thus increased organic knowledge, experience, and information played a positive role for farmers who believed organic farming would produce net benefits. Moreover, for farmers showing positive intention toward adopting agricultural practices, government initiatives were very important, including the academic and private sectors, in providing information, knowledge, conversion processes, certification, standards, and quality for market requirements. Farm practices have changed over time in response to new technologies, markets, and policies. Concepts related to agriculture, health, and 
the environment have been introduced, changing the adaptation of farm-level practices. The concept of good farming has been applied for agricultural transformation from conventional to organic agricultural practices. Initiatives should pay attention to informing consumers and raising the demand for fresh markets and further international markets.

Northern Thai farmers had direct effects on agricultural chemicals while environmental and health concerns had increased in the market. Consumers prefer products that meet organic quality standards, and such products benefit the environment and sustainable agriculture. Consumers tended to support organic agriculture and, on average, were willing to pay a higher price premium for organic produce - at least 24\% (Yiridoe, Bonti-Ankomah, \& Martin, 2005). On the other hand, scientific communities and industrial professional agriculture rejected organic farming because of the high cost of production and an unproductive system (Stanhill, 1990).

\section{RECOMMENDATIONS}

Effective organic agriculture support should explicitly consider two factors as key in decision making. First, market support by allowing the sale of organic products in private markets (modern trade) and premium markets (organic/green markets). Second, farmers are likely to consider an incremental step-by-step approach to adapting to organic agriculture. These may affect the decision of farmers to switch to organic agriculture. As a future suggestion, governments should establish regulations with more incentives for farmers to change to organic agriculture:

1) Regulation should support equipment and input factors, and funding resources.

2) Regulation of incentives for conventional farmers to form organic farming groups and motivate older members to join these groups.

3) Regulation should focus on the sustainability of organic farming by promoting the benefits of organic cultivation and encouraging continuous and expansive support of organic farming.

4) Regulation should underpin support knowledge, technology, training, standards, and extension to produce high quality and high yields for organic farmers.

As an additional recommendation, organic farming should include these developments: research, extension, farmers, and community. A new of generation farmers have important roles in helping to create, develop, inform, and educate their communities.

Funding: This study received no specific financial support.

Competing Interests: The author declares that there are no conflicts of interests regarding the publication of this paper.

Views and opinions expressed in this study are those of the authors views; the Asian Journal of Agriculture and Rural Development shall not be responsible or answerable for any loss, damage, or liability, etc. caused in relation to/arising out of the use of the content.

\section{REFERENCES}

Ajzen, I. (1991). The theory of planned behavior. Organizational Behavior and Human Decision Processes, 50(2), 179-211. Available at: https://doi.org/10.1016/0749-5978(91)90020-T.

Ajzen, I., \& Fishbein, M. (2005). The influence of attitudes on behavior. The Handbook of Attitudes (pp. 173-221). Mahwah: Erlbaum.

Asadollahpour, A., Najafabadi, M. O., \& Hosseini, S. J. (2016). Modeling behavior pattern of Iranian organic paddy farmers. Paddy and Water Environment, 14(1), 221-229. Available at: https://doi.org/10.1007/s 10333-015-0492-0.

Best, H. (2010). Environmental concern and the adoption of organic agriculture. Society and Natural Resources, $23(5)$, $451-468$. Available at: https://doi.org/10.1080/08941920802178206.

Buerkert, A., \& Schlecht, E. (2017). Organic agriculture in developing countries: Status quo and challenges. Rural, 21.

Constance, D. H., \& Choi, J. Y. (2010). Overcoming the barriers to organic adoption in the United States: A look at pragmatic conventional producers in Texas. Sustainability, 2(1), 163-188. Available at: https://doi.org/10.3390/su2010163.

Cranfield, J., Henson, S., \& Holliday, J. (2010). The motives, benefits, and problems of conversion to organic production. Agriculture and Human Values, 27(3), 291-306. Available at: https://doi.org/10.1007/s10460-009-9222-9.

Cristache, S.-E., Vuță, M., Marin, E., Cioacă, S.-I., \& Vuţă, M. (2018). Organic versus conventional farming-A paradigm for the sustainable development of the European countries. Sustainability, 10(11), 4279. Available at: https://doi.org/10.3390/su10114279.

Darnhofer, I., Lindenthal, T., Bartel-Kratochvil, R., \& Zollitsch, W. (2010). Conventionalisation of organic farming practices: From structural criteria towards an assessment based on organic principles. A review. Agronomy for Sustainable Development, 30(1), 67-81. Available at: https://doi.org/10.1051/agro/2009011.

Fishbein, M., \& Ajzen, I. (1975). Theories of attitude (pp. 335-383). New York: Addison Wesley.

Greene, W. H. (2003). Econometric analysis. New Jersey: Prentice-Hall.

Janssen, M., \& Hamm, U. (2014). Governmental and private certification labels for organic food: Consumer attitudes and preferences in Germany. Food Policy, 49, 437-448. Available at: https://doi.org/10.1016/j.foodpol.2014.05.01 1.

Karki, L., Schleenbecker, R., \& Hamm, U. (2011). Factors influencing a conversion to organic farming in Nepalese tea farms. Journal of Agriculture and Rural Development in the Tropics and Subtropics, 112(2), 113-123.

Kirchner, C. (2015). Overview of participatory guarantee systems in 2014. Frick, Switzerland: In the World of Organic Agriculture; Statistics and Emerging Trends 2015: Research Institute of Organic Agriculture (FiBL). Switzerland. pp. 33-51.

Koesling, M., Flaten, O., \& Lien, G. (2008). Factors influencing the conversion to organic farming in Norway. International Journal of Agricultural Resources, Governance and Ecology, 7(1-2), 78-95. Available at: https://doi.org/10.1504/ijarge.2008.016981. 
Lusk, J. L., \& Schroeder, T. C. (2004). Are choice experiments incentive compatible? A test with quality differentiated beef steaks. American Journal of Agricultural Economics, 86(2), 467-482. Available at: https://doi.org/10.1111/j.00925853.2004.00592.x.

O'Riordan, T., \& Cobb, D. (2001). Assessing the consequences of converting to organic agriculture. Journal of Agricultural Economics, 52(1), 22-35. Available at: https://doi.org/10.1111/j.1477-9552.2001.tb00907.x.

Offermann, F., Nieberg, H., \& Zander, K. (2009). Dependency of organic farms on direct payments in selected EU member states: Today and tomorrow. Food Policy, 34(3), 273-279. Available at: https://doi.org/10.1016/j.foodpol.2009.03.002.

Office of the National Economic and Social Development Board (NESDB). (2020). Economic report 2019.,Thailand. 1-4.

Pardthaisong, L., Sin-ampol, P., Suwanprasit, C., \& Charoenpanyanet, A. (2018). Haze pollution in Chiang Mai, Thailand: A road to resilience. Procedia Engineering, 212, 85-92. Available at: https://doi.org/10.1016/j.proeng.2018.01.012.

Schoonbeek, S., Azadi, H., Mahmoudi, H., Derudder, B., De Maeyer, P., \& Witlox, F. (2013). Organic agriculture and undernourishment in developing countries: Main potentials and challenges. Critical Reviews in Food Science and Nutrition, 53(9), 917-928. Available at: https://doi.org/10.1080/10408398.2011.573886.

Shaban, A. (2015). Factors influencing farmers' decision to shift to organic farming: The case of Gaza Strip. British Journal of Economics, Management and Trade, 5(1), 78-87. Available at: https://doi.org/10.9734/bjemt/2015/11708.

Stanhill, G. (1990). The comparative productivity of organic agriculture. Agriculture, Ecosystems and Environment, $30,1-26$. Available at: https://doi.org/10.1016/0167-8809(90)90179-H.

Terano, R., Mohamed, Z., Shamsudin, M. N., \& Latif, I. (2015). Factors influencing intention to adopt sustainable agriculture practices among paddy farmers in Kada, Malaysia. Asian Journal of Agricultural Research, 9(5), 268-275. Available at: https://doi.org/10.3923/ajar.2015.268.275.

Thamaga-Chitja, J., \& Hendriks, S. L. (2008). Emerging issues in smallholder organic production and marketing in South Africa. Development Southern Africa, 25(3), 317-326. Available at: https://doi.org/10.1080/03768350802212113.

Ullah, A., Shah, S. N. M., Ali, A., Naz, R., Mahar, A., \& Kalhoro, S. A. (2015). Factors affecting the adoption of organic farming in Peshawar-Pakistan. Agricultural Sciences, 6(06), 587-593. Available at: https://doi.org/ 10.4236/as.2015.66057.

Vairo, D., Häring, A. M., Dabbert, S., \& Zanoli, R. (2009). Policies supporting organic food and farming in the EU: Assessment and development by stakeholders in 11 European countries. Journal of International Food ङ Agribusiness Marketing, 21(23), 214-227. Available at: https://doi.org/10.1080/08974430802589733.

Wheeler, S. A. (2008). What influences agricultural professionals' views towards organic agriculture? Ecological Economics, 65, 145-154. Available at: https://doi.org/10.1016/j.ecolecon.2007.05.014.

Willer, H., \& Lernoud, J. (2019). The world of organic agriculture. Statistics and emerging trends 2019. Research Institute of Organic Agriculture FiBL and IFOAM Organics International.

Yanakittkul, P., \& Aungvaravong, C. (2020). A model of farmers intentions towards organic farming: A case study on rice farming in Thailand. Heliyon, 6(1), e03039. Available at: https://doi.org/10.1016/j.heliyon.2019.e03039.

Yiridoe, E. K., Bonti-Ankomah, S., \& Martin, R. C. (2005). Comparison of consumer perceptions and preference toward organic versus conventionally produced foods: A review and update of the literature. Renewable Agriculture and Food Systems, 20(4), 193-205. Available at: https://doi.org/10.1079/raf2005113. 